\title{
The Impact of Climate Change on Pastoralist Livelihoods in Ethiopia: A Review
}

\author{
Tariku Ayele ${ }^{* 1} \quad$ Diba Dedecha ${ }^{2} \quad$ Daniel Duba ${ }^{3}$ \\ 1.Bule Hora University, College of Agricultural Sciences, Department of Agricultural Economics, Postal code: \\ +219 , Bule Hora, Ethiopia \\ 2.Bule Hora University, College of Agricultural Sciences, Department of Animal and Range Sciences, Postal \\ code: +219 , Bule Hora, Ethiopia \\ 3.Bule Hora University, College of Agricultural Sciences, Department of Horticultural Sciences, Postal code: \\ +219 , Bule Hora, Ethiopia
}

\begin{abstract}
Pastoralism contributed a lot to the economy of the Africa. In Ethiopia, about 10 million pastoralists rely on animal husbandry as a key source of wealth and subsistence. The livestock sub-sector accounts for $20 \%$ of Ethiopia's GDP, with the national herd inhabiting Ethiopia's vast lowland periphery. So as to support pastoralists in Ethiopia, governmental and non-governmental organizations (NGOs), and amongst other actors, have intervened in various ways. Notwithstanding those remarkable efforts, pastoralist in different parts of Ethiopia operates over increasingly degraded rangeland due to increasing bush encroachment, population growth, agricultural encroachment, land degradation, blocked migration routes and conflict triggered over scarce natural resources. Having this fact, this review was initiated with the aim of exploring pastoral livelihood system in Ethiopia and impacts of climate change on pastoral livelihoods. Reviewed empirical evidence shows that, pastoralist in Ethiopia have engaged on various economic activities which include livestock rearing, crop farming, petty trade, hand craft activities, wood and charcoal sale and casual labor. Moreover, changes in climatic factors directly affected natural resources, livestock yields, caused animal and human disease epidemics, and loss of animals in pastoral areas. Therefore, attention should be given on strengthening pastoralist livelihood diversification through providing training on entrepreneurship, how to pool capital together to finance their economic activities, and ensuring finance and market access for pastoralist. As they are living in water scarce environment, special attention should also be given on encouraging participatory soil and water conservation practices, communal watershed and rangeland management.
\end{abstract}

Keywords: Pastoralism, Livelihood, Climate change

DOI: $10.7176 / \mathrm{JRDM} / 63-02$

Publication date:March $31^{\text {st }} 2020$

\section{INTRODUCTION}

Pastoralists inhabit different parts of the world, including Africa, Central Asia, the Arctic and southern Europe. It includes thirty six (36) countries, extending from the West of Sahelian to the Eastern Africa's rangelands and the Horn and the nomadic populations of Southern Africa, with an estimate of 268 million pastoralists (Blench, 2001; AU, 2010; Dong et al., 2011). Africa's dry lands are the center for pastoralists who depend on extensive livestock production system, mainly cattle, camels, sheep and goats, as their most important source of livelihood, food security, nutrition, income and wellbeing (AU, 2010). Livestock rearing in pastoral areas involves movement from one place to other to access publicly managed natural resources (FAO, 2018a). Drylands in East Africa (both arid and semi-arid lands) are huge in areas which account for $60 \%$ to $100 \%$ of the land cover of Ethiopia, Uganda, Kenya, Sudan, Somalia and Djibouti (FAO, 2008). Scholars increasingly agree that pastoral eco-systems are suited to the pastoralist way of life (Brooks, 2006), which after all has evolved and existed successfully in these landscapes for a long. The economic base of aarid and semi-arid lands in East Afrca is mainly based on animal herding which operates in resource scarce area, and climatic variables fluctuation which demands flexibility of movement seasonally. It is often this very flexibility which is a root cause of the political, social and economic marginalization which pastoralists find them in today (Brooks, 2006).

Pastoralism contributed a lot to the economy of the Africa. It is the source for the supply of millions of animals to both regional and global markets through livestock trade channels that link local, regional and cross border markets to neighboring countries and global markets.Generally, pastoralist contributes $10 \%$ to $44 \%$ to the gross domestic product (GDP) of African countries (AU, 2010). Eastern African countries such as Somalia, Sudan, and Ethiopia are known as major exporters of livestock to the Gulf States. In West Africa, the livestock sector contributes 5\% to $44 \%$ to the agricultural Gross Domestic Product (GDP) (UNDESA, 2007). Pastoralism is a cultural and economic system that is determined by social structure, resource management, productivity, trade and social and welfare mechanisms in communities founded on livestock rearing as a primary economic activity (Nori et al., 2008). In Ethiopia, the livestock sub-sector accounts for $20 \%$ of Ethiopia's GDP, with the national herd inhabiting Ethiopia's vast lowland periphery covering $60 \%$ of the total land area. About 10 million pastoralists 
rely on animal husbandry as a key source of wealth and subsistence (Samuel, 2016).

In different regions of the world, In the last three decades, pastoralism has faced processes of change that implies the declining ability of pastoral systems to absorb shocks they are facing and cope up to changes. As a result of increasing destitution, there have been growing social differentiation and inequalities within the pastoral communities (FAO, 2018a). While the poor fall out of pastoralism and become destitute, the wealthier stay in pastoralism and adopted more commercialized approaches (Catley and Aklilu, 2013). In addition, the pastoralist population is growing at an estimated rate of $2.5 \%$ to $3 \%$ per annum. Therefore, due to lack of sustained way of life and existing shocks in pastoral areas, people have to move away from pastoralism (AU, 2010). These observed changes in pastoralist widen the differences in asset between wealthy and poor segments of pastoralist and make it hard to return back to pastoralism latter on (Catley and Aklilu, 2013; Aklilu et al., 2016). The increasing destitution and decreasing standard of living take place against a backdrop of lack of infrastructure, poor education and health service, and deteriorating security situations. Such a situation has serious implications for the viability, adaptive capacity and resilience of the pastoral livelihood system (Catley, 2017).

Cognizant of natural and made shocks like erratic rainfall pattern, drought, floods, and conflicts to which pastoralists are vulnerable, governmental institution and non-governmental organizations (NGOs), and amongst other actors, have been attempted to support pastoralists in Ethiopia in various ways from improving animal and human health, supporting and introducing diversification activities (often based on rangeland resources), creating and strengthening access to markets, natural resource access (such as water access), strengthening traditional institutions and improving rangeland management (Solomon, n.d; Berhanu et al., 2017). Notwithstanding those remarkable efforts, still there remains further works to be done so as to transform their livelihood system on sustainable manner. Today, pastoralist in Ethiopia operates over a circumscribed area of increasingly degraded rangeland now suffering from increasing bush encroachment.The rangelands are shrinking through various factors including population growth, agricultural encroachment, land degradation, blocked migration routes and conflict triggered amongst others by scarce natural resources (Eyasu and Feyera, 2010). Having this fact, this review was initiated to explore pastoral livelihood system in Ethiopia with the specific objectives of reviewing major economic activities practiced by pastoral communities and impacts of climate change on pastoral livelihoods.

\section{REVIEWS}

\subsection{Overview of Livelihood System of Pastoral Communities in Ethiopia}

Ethiopian pastoralists who are mainly found in four lowland regions, Afar, Oromiya, Somali and the Southern Nations, Nationalities and People's (SNNP) regional states and partly in Gambella and Benishangul areas involved in various livelihoods systems (Sileshi, 2016). Livestock rearing is dominant means of livelihood for pastoral communities (Solomon, n.d; Birch, 2018). Nationwide the livestock sub-sector accounts for $20 \%$ of Ethiopia's GDP, with the national herd inhabiting Ethiopia's vast lowland periphery covering $60 \%$ of the total land area. About 10 million pastoralists rely on animal husbandry as a key source of wealth and subsistence (Samuel, 2016). In addition to the dominant livestock sector, pastoral communities have long been involved in different economic activities and derive a significant portion of their subsistence from activities such as farming, migration to towns, petty trading, selling of charcoal and fuel wood wage labor, caravan trade, and crafts. This shows that, there are a huge variety of non-livestock livelihood strategies practiced by pastoralists in different areas (Sileshi, 2016). Empirical evidence by Doyo (2017) shows that Borena pastoralist of Yabello district derive $72.49 \%$ of their income from pastoral and dry land farming (cereal crop production, livestock and livestock product sale), $21.30 \%$ from high return non-pastoral non-farm activities (livestock trade, opening bars at local town, renting house at town, vehicles transportation) and $6.21 \%$ from low return non-pastoral non-farm activities which includes petty trade like shopping, hand craft activities, remittance, wood and charcoal sale and casual labor.

According to the same source, being the livestock sector predominant in Borana pastoralists of Yabello district, four major species of livestock such as cattle, sheep, goat and camels are kept by herders. Cattle are the most preferred types of livestock and considered as the major wealth indicator in Borana community. Sheep and goats, on the other hand, are the major sources of income for household for meeting consumption of food or non food needs. Camels also introduced recently in to the production system. A study conducted by Amare (2018) also confirms that, similar livelihood systems are practiced by Borena pastoralist. Transhumance system is identified as the main livestock production system in Borena. Transhumance system featured by strategic seasonal movement of pastoralists along with their animals in search of pasture along with water source for human and livestock enable to cope up the effect of relatively longer dry period and returns back to their original place during the onset of the rainy season (RREDP, n.d). Even though livestock production predominantly forms the basis of the economy in pastoral areas of Borena, still the productivity of milk (i.e. milk liter/ animal /day) in the area is low with cattle productivity ranging between 0.5 liters and 2.5 liters and an estimated average of 1.5 liters/cattle. The average daily milk yield of camel and shoats in Borena pastoral areas is estimated to 3.5 liters and 0.25 liters respectively (RREDP, n.d).

Moreover, Smith et al., (2015) identified farming/crop production and sales, livestock production and sales, 
wage labor, salaried work, sale of wild/brush products, self-employment, sale of other non-livestock assets, remittances, and gifts/inheritance as common means of livelihood for pastoralists in Borena and Jigjiga. Pastoralist from Gambella region shares the same livelihoods including fishery (Yilebes, 2017). A finding by Berhanu et al., (2017) shows about $51 \%$ of households in Afar region engaged in purely pastoral livelihood system where $100 \%$ of income received from livestock rearing followed by $24.1 \%$ agro-pastoral household where members own livestock but do not move them from their private land (i.e. livestock are kept in enclosures) with crop growing and with other income-generation activities. Similarly, 36.1\% of households in Somali region are purely pastoralist with no permanent residence, no crop growing and other source of income while $34.8 \%$ are pastoral household where members move mobile livestock regularly to agreed grazing areas within the woreda, with milking/weak animals kept around the settlement, with no crop growing and no other income-generation activities.

About $40.9 \%$ and $43.9 \%$ of households in SNNPR (South Omo and Benchi Maji) and Oromia region (Borena) respectively are agro-pastoralist where members move mobile livestock regularly to agreed grazing areas within the woreda and with no other sources of income. About $29.4 \%$ of households in SNNPR (South Omo and Benchi Maji) are pastoral household where members move mobile livestock regularly to agreed grazing areas within the woreda, with milking/weak animals kept around the settlement (i.e. a 'satellite' system), with no crop growing and no other income-generation activities while $35.2 \%$ of households in Oromia region (Borena) were agro-pastoral household where members own livestock but do not move them from their private land with crop growing and with other income-generation activities (Berhanu et al., 2017). Cash income from the livestock and its products sale is the most important contributor to pastoral household. The second most important source of cash income varies from region to region. While crop farming is second most important source of cash income in Borana and SNNPR, businesses are second most important source of cash income in the Somali region. In Afar, miscellaneous cash income sources such as productive safety net program (PSNP) and transfers are second most important source of cash income (Berhanu et al., 2017). Even if Borena pastoralists are engaged in varied economic activities, their participation in non/off-farm activities are constrained by a number of factors which includes lack of capital, security and peace, lack of entrepreneurial skill, inaccessibility of the markets and lack of employment (Samuel, 2016).

\subsection{Pastoral Livestock Production System in Ethiopia}

Pastoral livestock production is a crucial element in the livelihoods and economies of Africa's drylands. The land's physical characteristics, climatic conditions and plant communities are well suited for mobile livestock production because the semiarid regions experience highly variable rainfall and drought, fodder availability fluctuates widely through time and space (Dong et al., 2011; Sidahmed, 2018; Krätli et al., 2018). Exploiting these environments requires mobility and flexibility to match available feed resources with the animal numbers and water at a site (Behnke et al., 1993). The mobility of pastoralists exploiting the animal feed resources along different ecological zones represents a flexible response to a dry and increasingly variable environment. It allows pastoral herds to use the drier areas during the wet season and more humid areas during the dry season. As a result, pastoral livestock are ensured sufficient high quality grazing. Mobility also allows pastoralists to mitigate the effect of unforeseen events, such as disease outbreaks (Niamir-Fuller, 1999). These strategies allow pastoralists to survive in difficult environments and create economic value out of otherwise fragile ecosystems. Therefore, constraints on pastoral mobility, such as changes in land use, tenure regulations and borders, can undermine the whole pastoral system. The adaptability and mobility of pastoralism in relation to resource variability have been undermined by factors including climate change, environmental degradation and pressures to increase agricultural production to feed a rapidly growing population. The low mean rainfall of the late twentieth century, combined with the technocratic approaches to development, has increasingly marginalized the traditional approaches to resource management and food security (Brooks, 2006). These factors resulted in rapid changes in land use and land control and compression of pastoralists' livelihood space. As a result, social conflicts between agriculturalists and pastoralists have increased, along with the problems associated with overgrazing and land resource deterioration. These changes have left many pastoralists living in a "world of insecurity, war, famine and drought" (Baxter, 1993). The Pastoral and agro-pastoral systems which are found in the lowlands are characterized by extensive production based largely on the rangeland as arid and semi-arid agro-ecology zones receive low moisture most of the year and feed is scarce in the dry season, pastoralists move their animals from place to place in search of feed and water. Such a management strategy helps them survive the dry season with minimum losses. This production system is associated with the purely livestock based nomadic and transhumance pastoral production systems based largely on range, primarily using natural vegetation (Matawork, 2016).

Pastoral/agro-pastoral production is the major system of production practiced in the lowland regions of Ethiopia where livelihoods are heavily dependent on livestock. Extensive livestock keeping is the backbone of the economies of the lowlands (FAO, 2018b). As EARO (2000) cited in FAO (2018b), in the lowlands of Ethiopia, livestock is comprised of large flocks and herds of sheep and goats, cattle and camels mainly transhumant, where only surplus are sold at local markets or trekked to major consumption centers. Cattle dominate the livestock 
population in pastoral and agro pastoral systems followed by camel, goats, and sheep. Cows constitute about 40 percent of the herd. Major pastoral areas extend from the north-eastern and eastern lowlands (Afar and Somali) to the southern and south-western lowlands (Borana and South Omo). Relatively larger flocks are maintained in the lowland (agro) pastoral systems. Approximately cattle keeping pastoral/agro-pastoral households are estimated to be 3.1 million with average herd size: 10-20; large herds of $>200$ heads are common too. Typical breeds are entirely indigenous breeds are kept. Feed types for cattle include predominantly communal rangeland pastures; crop residues are used to a limited extent in agro-pastoral areas (FAO, 2018b). The major feed resources for sheep and goats include grazing on communal natural pasture, crop stubble, fallow grazing, roadside grazing, crop residues, browses, and non-conventional feeds (household food leftovers, weeds, crop tillers and fillers)(Matawork, 2016; FAO, 2018b). Production of improved forages, improvement of low quality feed sources such as crop residues and supplementary feeding (except fattening) is almost non-existent (Solomon et al., 2008). Boreholes, deep wells, dams, rain water, and rivers are major sources of water. Milk production per unit area is low and highly seasonal. However, milk is usually produced in excess during the wet season and is either sold fresh to nearby urban centres or processed into butter to be traded with the highlanders in the peripheral markets for grains. The reliance of the agro-pastoral and pastoral systems on the overgrazed natural resource base makes them most vulnerable to climate change.

\subsection{Impacts of Climate Change on Pastoral Livelihoods}

Pastoral areas in Ethiopia are characterized by frequent drought with high livestock mortality which often results in threatening viability of pastoral livelihood, famine and deaths in human population (Solomon, 2016). Increasing pressures due to natural and man-made shocks that are leading to imbalance between these populations and the resources they depend on to sustain themselves and ongoing climate change is expected to increase the unpredictability of rainfall, leading to more frequent droughts and floods (Smith et al., 2015). These factors exacerbated livelihood challenge among pastoralists as it is hardly to understand pastoralists' livelihood system independent of natural resources. In a study conducted by BER (2016) to assess the degree of interdependency between livelihood strategies and natural resources in three agro-ecological zones of Bale Eco-Region, on average, next to midland (97.75\%), high degree of dependency on natural resources (Land, water, forests, and soil) was observed in lowlanders with average percentage of $97.5 \%$ followed by highland $(93.75 \%)$. This indicates that pastoralist livelihoods are highly tied with natural resources and persistence in climate change causes devastation of natural resources that will in turn pose pastoralist livelihood hardship by affecting their dominant livelihood base.

Climate change and variability in Ethiopia poses particular risks to poor farmers and pastoralists who have an immediate daily dependence on climate sensitive livelihoods and natural resources. In addition to the physiological effects of higher temperatures on individual animals, loss of animals as a result of droughts and floods, or disease epidemics related to climate change may thus increase. Indirect effects may be felt via ecosystem changes that alter the distribution of animal diseases or the supply of feed. Moreover, the spatial distribution and availability of pasture and water are highly dependent on the pattern and availability of rainfall. Changes in the patterns of rainfall and ranges of temperature affect feed availability, grazing ranges, feed quality, weed, pest and disease incidence (Tiruneh and Tegene, 2018). Climate change characterized by changing rainfall patterns and temperature increases will affect poor Ethiopian people whose survival depends on rain-fed agriculture through farming and/or pastoralism (Ludi et al., 2011). According to Venton et al., (2012), the frequency of droughts and floods has increased in many areas of Ethiopia in recent years, and these people are already struggling to cope with the impacts of current climate variability and poverty. NAPA (2007) cited in Reid et al., (2013) identifies pastoralists as amongst those most vulnerable to climate change impacts and states that "drought is the single most important climate related natural hazard impacting the country. In southern Ethiopia, specifically in Borana zone, drought frequency in the region used to be every 6-8 years, but has now increased to every 1-2 years (Reid et al., 2013).

According to Eyasu and Feyera (2010), livestock numbers in pastoralist and agro-pastoralist communities of Southern Ethiopia (Borena and Karrayyu) are declining dramatically, land degradation is increasing, people are becoming more vulnerable to drought and famine and resource-based conflicts are increasing in severity. In Borana areas, climate change affected livestock production by causing feed shortage, shortage of water, reduced productivity, and decreased mature weight and/or longer time to reach mature weight (Tiruneh and Tegene, 2018). In addition, as explained in Reid et al., (2013), climate change will provide an additional stressor for Borana communities. The following table illustrates how climate change affects livelihoods in the Borana Zone. 


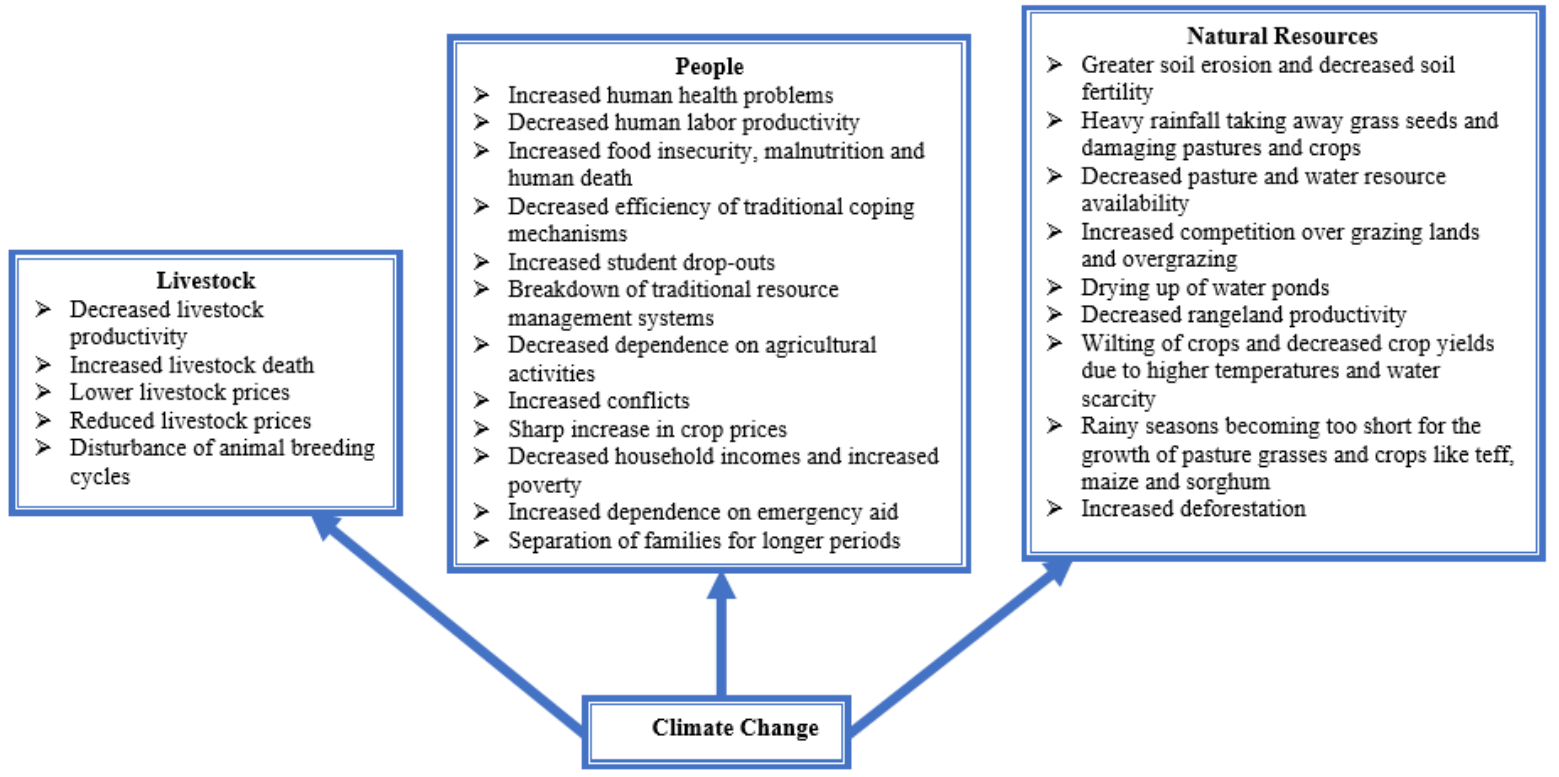

Figure 1: Impacts of climate on local livelihoods in the Borana Zone

Source: Authors' sketch based on Reid et al., (2013)

\section{CONCLUSION AND RECOMMENDATION}

Now a day, transformation of pastoral communities' livelihood has become a subject of focus worldwide. Given vulnerability of pastoral community to natural and manmade shocks due to the environment within which they are living, it is impossible to bring sustainable transformation on pastoral communities livelihood without understanding and influencing economic activities to which they are engaged in and how their livelihood interact with existing and changing environment. Cognizant of it, this review was aimed at exploring major economic activities practiced by pastoral communities and how change in climate would affect pastoral communities' livelihood system in Ethiopia. Reviewed empirical evidence shows that, pastoralist in Ethiopia, in addition to livestock rearing which form their dominant livelihood base, they engaged in various economic activities which include crop farming, petty trade, hand craft activities, wood and charcoal sale and casual labor. Even if they are engaged in diversified livelihoods, their degree of participation is constrained by different factors such as capital shortage, poor entrepreneurial skill, and inaccessibility of the markets. Moreover, changes in climatic factors such as temperature, precipitation and the frequency and severity of extreme events like droughts directly affected livestock yields in pastoral areas. Therefore, attention should be given on strengthening pastoralist livelihood diversification through providing training on entrepreneurship, how to pool capital together to finance their economic activities, and ensuring finance and market access for pastoralist. As they are living in moisture deficit areas, the focus should be on encouraging participatory soil and water conservation, and watershed management.

\section{REFERENCES}

African Union. (2010). Policy framework for pastoralism in Africa: Securing, protecting and improving the lives, livelihoods and rights of pastoral communities, Addis Ababa. [Cited 11 July 2018]. au.int/sites/default/files/ documents/30240-doc-policy_framework_for_pastoralism.pdf

Aklilu, Y., Lemma, G., Deng, L., \& Abdullahi, S. (2016). The impact of conflict on the livestock sector in South Sudan. Juba, South Sudan: Food and Agriculture Organization of the United Nations.

Aklilu, Y., Lemma, G., Deng, L., \& Abdullahi, S. (2016). The impact of conflict on the livestock sector in South Sudan. Juba, South Sudan: Food and Agriculture Organization of the United Nations.

Amare Molla. (2018). Determinants of livelihood diversification strategies in Borena pastoralist communities of Oromia regional state, Ethiopia, Agriculture \& Food Security, 7(41):

Baxter, P. T. W. (1993). The "new" East African pastoralist: An overview. In J. Markahis, ed. Conflict and the decline of pastoralism in the Horn of Africa, pp. 145-146. London, United Kingdom: Macmillan.

Behnke, R. H., Scoones, I., \& Kerven, C., eds. (1993). Range ecology at disequilibrium: New models of natural variability and pastoral adaptation in African savannas. Nottingham, United Kingdom: Overseas Development Institute.

BER(BALE ECO-REGION). (2016). Economic Activities of Local Communities and Their Dependence on Natural Resources in the Bale Eco-Region, SHARE Bale Eco-Region Research Report Series no. 3

Berhanu Gebremedhin, Mengistu Woldehanna, Fiona Flintan, Barbara Wieland and Jane Poole. (2017). Baseline 
Survey Report For The Regional Pastoral Livelihoods Resilience Project In Ethiopia, ILRI PROJECT REPORT.

Birch I. (2018). Economic growth in the lowlands of Ethiopia: Knowledge, Evidence and Learning for Development, Helpdesk Report

Blench, R.(2001). You can't go home again: Pastoralism in the new millennium. London, United Kingdom: Overseas Development Institute.

Brooks, N. (2006). Climate change, drought and pastoralism in the Sahel. Discussion note for the World Initiative on Sustainable Pastoralism. Gland, Switzerland: International Union for Conservation of Nature.

Catley, A. (2017). Pathways to resilience in pastoralist areas: A synthesis of research in the Horn of Africa. Boston, MA: Feinstein International Center, Tufts University.

Catley, A., \& Aklilu, Y. (2013). Moving up or moving out? Commercialization,growth and destitution in pastoralist areas. In A. Catley, J. Lind, \& I. Scoones, eds. Pastoralism and development in Africa: Dynamic change at the margins, pp. 85-97. Abingdon, United Kingdom, and New York, NY: Routledge.

Dong, S., Wen, L., Liu, S., Zhang, X., Lassoie, J. P., Yi, S., \& Li, Y. (2011).Vulnerability of worldwide pastoralism to global changes and interdisciplinary strategies for sustainable pastoralism. Ecology and Society, 16(2): 10.

Doyo Kena. (2017). Livelihood Diversification Strategies among the Borana Pastoral Communities of Yabello District, Oromia Region, Ethiopia. A MSc Thesis submitted to Haramaya University, Haramaya, Ethiopia.

EARO (Ethiopian Agricultural Research Organization). (2000). National Small Ruminants Research Strategy Document. EARO, Addis Ababa, Ethiopia.

Eyasu Elias and Feyera Abdi. (2010). Putting Pastoralists on the Policy Agenda: Land Alienation in Southern Ethiopia.

FAO. (2008). Proceedings of Sub-Regional Workshop on Managing East African Rangelands for Better Response to Feed Crisis. FAO: Addis Ababa.

FAO. (2018a). Pastoralism in Africa's drylands. Rome. 52 pp. Licence: CC BY-NC-SA 3.0 IGO.

FAO .(2018b). Livestock production systems spotlight Cattle sectors in Ethiopia

Krätli, S., Sougnabé, P., Staro, F., \& Young. H. 2018. Pastoral systems in Dar Sila Chad: A background paper for Concern Worldwide. Boston, MA: Feinstein International Center, Tufts University.

Ludi, E., Getnet, M., Wilson, K., Tesfaye, K., Shimelis, B., Levine, S. and L. Jones. (2011). Preparing for the future? Understanding the Influence of Development Interventions on Adaptive Capacity at Local Level in Ethiopia. Africa Climate Change Resilience Alliance (ACCRA) Ethiopia Synthesis Report. Overseas Development Institute, London.

Matawork Milkias. (2016). Review on Small Ruminant Production, Marketing and Constraints in Ethiopia. Advances in Life Science and Technology, 48:2224-7181

NAPA. (2007). Climate Change National Adaptation Programme of Action (NAPA) of Ethiopia. The Federal Democratic Republic of Ethiopia, Ministry of Water Resources, National Meteorological Agency. Addis Ababa, Ethiopia. GEF/UNDP.

Niamir-Fuller, M. (1999). Managing mobility in African rangelands:The legitimization of transhumance. London, United Kingdom:Intermediate Technology.

Nori M., Taylor M., and Sensi A. (2008). Browsing on fences. Pastoral land rights, livelihoods and adaptation to climate change. IIED issue paper no. 148.

Reid H, Faulkner L, and Weiser A. (2013). The Role of Community Based Natural Resource Management in Climate Change Adaptation in Ethiopia. IIED Climate Change Working Paper No.6

RREDP (Regional Resilience Enhancement against Drought Project). (n.d). Value Chain Analysis of Milk and Milk Products in Borana Pastoralist Area, CARE-ETHIOPIA.

Samuel Gebreselassie. (2016). Economic Linkages Between Pastoralists And Farmers In Ethiopia: Case Study Evidence From Districts In Afar/Amhara And Oromia. A Summary of research conducted through the AKLDP Capacity Building Grant.

Sidahmed, A., E. (2018). Recent trends in drylands and future scope for advancement. In M.K. Gaur \& V.R. Squires, eds. Climate variability impacts on land use and livelihoods in drylands, pp 21-57. Switzerland, Springer International Publishing, AG.

Sileshi Mengistu. (2016). Challenges Of Livelihood Diversification In Pastoral Lands Of Ethiopia: Evidence From South Omo Pastoralists. International Journal Of Scientific \& Technology Research, 5(9): 2277-8616.

Smith L, Frankenberger T, Langworthy B, Martin S, Spangler T, Nelson S, and Downen J. (2015). Ethiopia Pastoralist Areas Resilience Improvement and Market Expansion (PRIME) Project Impact Evaluation: Baseline Survey Report Volume 1: Main Report.

Solomon Desta. (n.d). Pastoralism and Development in Ethiopia: Economic Focus. A paper presented at Ethiopian Economic Association.

Tiruneh S and Tegene F. 2018. Impacts of Climate Change on Livestock Production and Productivity and Different Adaptation Strategies in Ethiopia. Journal of Nutrition and Health Sci 5(4): 401 
UNDESA (2007). World Urbanization Prospects. Retrieved on 28 August, 2019 from: http://esa.un.org/unup/index.asp

Venton, C. C., Fitzgibbon, C., Shitarek, T., Coulter, L. and O. Dooley. 2012. The Economics of Early Response and Disaster Resilience: Lessons from Kenya and Ethiopia.

Yilebes Addisu. 2017. Livelihood strategies and diversification in western tip pastoral areas of Ethiopia, Pastoralism: Research, Policy and Practice 7(9): 